\title{
Becoming Family Farmers: The Contribution of the Existential Ontological Perspective to the Social Learning for Sustainability Theory
}

\author{
Marcia Juliana d'Angelo ${ }^{1, *(D)}$, Janette Brunstein ${ }^{2}$ and Jones Madson Telles ${ }^{1}$ \\ 1 Management Department, Fucape Business School, Vitória 29075-505, Brazil; jonestelles368@gmail.com \\ 2 Postgraduate Program in Administration, Universidade Presbiteriana Mackenzie, São Paulo 01302-907, Brazil; \\ janette.brunstein@mackenzie.br \\ * Correspondence: marciadangelo@fucape.br or mjdangelo@terra.com.br
}

check for updates

Citation: d'Angelo, M.J.; Brunstein,

J.; Telles, J.M. Becoming Family

Farmers: The Contribution of the Existential Ontological Perspective to the Social Learning for Sustainability Theory. Sustainability 2021, 13, 8186. https://doi.org/10.3390/su13158186

Academic Editor: Hyo-Sun Jung

Received: 7 June 2021

Accepted: 6 July 2021

Published: 22 July 2021

Publisher's Note: MDPI stays neutral with regard to jurisdictional claims in published maps and institutional affiliations.

Copyright: (c) 2021 by the authors. Licensee MDPI, Basel, Switzerland. This article is an open access article distributed under the terms and conditions of the Creative Commons Attribution (CC BY) license (https:/ / creativecommons.org/licenses/by/ $4.0 /)$.

\begin{abstract}
This research examines social learning for sustainability (SLfS), particularly in its social dimension. Few studies have discussed or advanced on the ontological issues of SLfS relating to who social actors are becoming. This study aims to describe and analyze how the process of SLfS facilitates Brazilian families who were at the base of the social pyramid (no income) to change the status from landless campers to family farmers with land moving up four levels in the social pyramid over a decade. The research is qualitative interpretative, based on narratives from semi-structured interviews with 16 social actors and document analysis. The results show the meaning of learning professional ways of being family farmers from an existential ontological perspective.
\end{abstract}

Keywords: social learning for sustainability; the base of the pyramid; family farmers; ontological perspective

\section{Introduction}

Social learning for sustainability (SLfS) is a process that emerges from a shared perception of issues (environmental, social, economic, political, cultural, spiritual, geographical, and so on) involving several social actors with multiple interests, conflicts, and power relations, and it is difficult to achieve an agreement. It means to learn together through social interactions, reflection, reflectivity, negotiation, informal communication, and collaboration to achieve sustainable small wins, changing attitudes and mindsets. Therefore, it encompasses the process from triggering the problem or situation to obtaining sustainable results [1-9].

The emphasis on SLfS studies has been on the epistemological issues-knowledge, relational, and technical skills. It has focused on questions such as what to learn, how to learn, who learns, whom to learn from, when to learn, where to learn, and why to learn [1-13].

Few studies have discussed and advanced on the ontological issues of SLfS relating to who social actors are becoming. That is, to discuss how SLfS influences the subjects involved in this process. For instance, Notaroberto and d'Angelo [9] analyzed the experience of a Brazilian social project and discussed how the various social actors involved are seeking dialogue, action, and cooperative knowledge to transform the lives of people with disabilities. Likewise, Chaves et al. [14] discussed how encounters between different ontologies could result in transformative and potentially transgressive learning, disrupting stubborn routines, norms, and hegemonic powers that tend to accelerate unsustainability in a Colombian Network of Sustainability.

Therefore, in the present paper, we aim to explore what it means to develop professional ways of being, where the emphasis shifts from knowing as an end in itself, to "becoming". The focus is on how acquiring new knowledge to obtain and run the land engages participants in "becoming" family farmers. 
This research contributes to this gap in the literature by aiming to analyze and describe how the process of SLfS facilitates Brazilian families who were at the base of the social pyramid (no income) to change the status from landless campers to family farmers, moving up four levels in the social pyramid over a decade.

Thus, the study contributes by discussing the ontological aspects relating to who social actors are becoming in a SLfS process: learning professional ways of being family farmers based on the frameworks of Dall'Alba [15] and Sandberg and Pinnington [16] of professional competence as ways of being. In this research, ontological thinking involves preparing aspiring farmers for the challenges of practicing dairy farming and coffee growing professionally.

Besides contributing to advances in the ontological aspects of SLfS, the study also covers both a demand for more research in SLfS, with a focus on the social dimension [17], and the need for more research in the area in different socio-ecological systems $[5,18]$. Hence, it meets the dimension of social sustainability proposed by Sachs [19]: reducing social inequalities by creating jobs and income. The study contributes to the challenges of the 2030 Agenda for Sustainable Development, proposed by the United Nations [20], mainly: (i) 'ending poverty in all its forms and everywhere through the access of poor and vulnerable people to property and control over land and promoting sustainable agriculture; (ii) ending hunger, achieving food security, and improving nutrition and promoting sustainable agriculture by increasing the income of family farmers through safe and equal access to land'. Furthermore, by investigating the ontological process of becoming a family farmer, the study seeks to better understand the processes involved in social learning for sustainability.

\section{Theoretical Background}

\subsection{Epistemological Aspects of SLfS Processes}

Many authors have sought to conceptualize and generate a framework to understand how the social learning process for sustainability (SLfS) occurs, based on several dimensions, as shown in Table 1 [1-6,9].

All these approaches have elements of SLfS that involve questions of epistemological nature: how to learn, whom to learn from, when to learn, why to learn, and what to learn. The reasons for learning-why learn-concern the resolution of environmental and social issues, such as water resources management [4]; an economic crisis that leads to a reconceptualization of the provision of public services [21] and employability of disabled people [9]; context governance, natural environment (air, soil, water quality, quantity, and biodiversity) $[1,2,4]$.

How to learn refers to reflection and reflexivity, system orientation and system thinking, integration and synthesis, negotiation and collaboration, participation and engagement, learning partnerships, learning platforms, learning values, and ethics [3]. It also refers to relational practices and social involvement in wider social units or communities of practice and social interaction [1,2,4]. For instance, it can be about learning in the rural communities of practice through informal networks and communications [8].

How learning occurs is also about a social exchange, using collaborative tools, materials, and resources and sharing the work [13]. It is learning by doing, for instance, by developing soft skills through experienced and trusted facilitators' engagement in climate change and food security. It is about 'bringing multiple stakeholders with diverse expertise and experience together in the alliances; crucial for initiating discussions and ensuring that the alliances are a safe space for open discussion and a diversity of viewpoints'. The reflection occurs in the iterative learning from capturing and sharing, for instance ([10], p. 6). Facilitation strategies also influenced the processual learning in an international knowledge alliance project for integrating education for sustainable development in higher education curricula. They are applied to achieving goals, addressing decisions in meetings, and workshops. In this project, the learning is also influenced by the personal context (level of the participant's involvement in the project and the level of their expectations) and group 
contexts (group norms, shared goals, and group dynamics); by experience processing ('the process in which participants intentionally reflect on previous experience, elaborate on its potential, and plan if or how it could be used for modifying existing action theories') ([11], p. 4361).

Table 1. Social learning for sustainability (SLfS) concepts.

\begin{tabular}{|c|c|}
\hline Authors & Social Learning for Sustainability (SLfS) Concepts \\
\hline $\begin{array}{l}\text { HarmoniCOP WP2 } \\
\text { Reference Document. } \\
\text { [1] }\end{array}$ & $\begin{array}{l}\text { Context (governance and physical systems), process (relational practices, social } \\
\text { involvement-problem framing, boundary management, negotiation strategies, } \\
\text { leadership and facilitation, interaction, allocation of resources, content } \\
\text { management), outcomes (relational and technical qualities) and feedback }\end{array}$ \\
\hline [2] & $\begin{array}{c}\text { Context governance, natural environment, participation, social relational issues, } \\
\text { relational practices, problem/tasks management issues, recognition of social } \\
\text { identities and stakeholder interdependency, generated knowledge, relational and } \\
\text { technical qualities }\end{array}$ \\
\hline [3] & $\begin{array}{l}\text { Reflection and reflexivity; system orientation and system thinking; integration and } \\
\text { synthesis; negotiation and collaboration, participation and engagement; learning } \\
\text { partnerships; learning platforms and learning values and ethics }\end{array}$ \\
\hline [4] & $\begin{array}{l}\text { Context (governance structure and natural environment technologies), process } \\
\text { (social/relational issues, relation of practices, problem/tasks issues; outcomes } \\
\text { (relational qualities social capital, technical qualities) and feedback }\end{array}$ \\
\hline [5] & $\begin{array}{c}\text { A change in understanding (change in attitudes, world views or epistemological } \\
\text { beliefs), wider social units or communities of practice, social interaction and } \\
\text { processes between } \\
\text { actors within a social network }\end{array}$ \\
\hline [6] & $\begin{array}{l}\text { Recognition of environmental problems and conflicts, re-learning a new way to } \\
\text { reconcile interests, transforming environmental crisis into opportunities for } \\
\text { sustainable business, structuring an implementation and model management for } \\
\text { developing a sustainable business, coordination of a strategy complex } \\
\text { implementation to support the business }\end{array}$ \\
\hline [9] & $\begin{array}{c}\text { Triggering the problem or situation, understanding the problem or situation, } \\
\text { building viable solutions, implementing the solution, obtaining sustainable results, } \\
\text { decision making, set of rules and legal instruments, epistemological and } \\
\text { ontological outcomes }\end{array}$ \\
\hline
\end{tabular}

Source: The authors based on the references depicted in the first column on the left.

In SLfS, in for-profit organizations, social learning involves coordinating complex solutions: multiple interests, conflicts of interest, power relations, learning spaces, and partnerships [6].

Who learns and whom to learn from concerns the voices participating in SLfS. In other words, 'the different groups and individuals as they work to improve the management of human and environmental interrelationships' ([3], p. 262). It also involves the various 'stakeholders to get desirable social outcomes in terms of joint project work or development of common attitudes' ([2], p. 141) or 'representatives from stakeholder groups regularly interact' [4]. These social actors could be families, children, students, working persons, jobseekers, refugees, migrants, or pensioners in community gardens [13].

When to learn ranges from triggering the problem or situation, understanding the problem or situation, building and implementing viable solutions, to obtaining sustainable results [9]. The social actors engage early in communities, enabling a wider group to design the context of climate change and food security [10]. Alternatively, emerging from the recognition of environmental problems and conflicts can come as re-learning a new way to reconcile interests, transforming environmental crisis into opportunities for sustainable business, structuring an implementation, and modelling management for developing sustainable business to the coordination of complex strategy implementation to support the business [6]. 
Finally, what is learned refers to sustainable results (outcomes), mainly relational and technical skills. The focus is on social actors involved with SLfS and their cognitions to learn about a problem and its solutions, to learn about the interests of all social actors, to learn tools, methods, and strategies for communicating, as well as attitudes and relational skills to deal with different views, interests, and knowledge $[1,2,4]$. It can comprise gardening and ecological conditions (production), politics of space (ownership, legal status), self-organization (organizational form, decision structure), and social enterprising (profit orientation, financing) [13]. Other types of learning can be content knowledge, personal development, teaching competence, and processual learning emerged from an international knowledge alliance project for integrating education for sustainable development in higher education curricula [11].

In other words, in these studies, the bottom-line has been the development and acquisition of knowledge, heuristics, and attitudes culminating in developing new skills. However, a SLfS process, in addition to being long and complex, brings together relevant elements that form the web of social learning, namely: (i) the natural environment (the land), the stage of the dispute; (ii) several social actors; (iii) diverse interests; (iv) conflicts of interest; (v) different power relations; (vi) dialogues, negotiations, and interaction; (vii) the use of different social learning spaces [6]. Therefore, there is also a need to discuss how SLfS influences the subjects involved in this process.

It is about understanding the phenomenon of SLfS in a similar way to what occurs in a professional education program, according to ([15], p. 34). In this approach, 'focus on epistemology occurs at the expense of ontological considerations relating to who students are becoming'. In a professional education program, Dall'Alba ([15], pp. 34-35) adds:

'While knowledge and skills are necessary, they are insufficient for skillful practice and transformation of the self-integral to achieving such practice. When we concentrate our attention on epistemology — or what students know and can do-we fail to facilitate and support such transformation. We expect professional education programs to lead to the transformations associated with this process of becoming, for example, from student to engineer, historian, or medical practitioner'.

\subsection{A Theoretical Lens to Understand the Ontological Aspects of a SLfS Process}

Drawing upon ontological ideas from Martin Heidegge- "being-in-the-world" —and Maurice Merleau-Ponty's notion of ambiguity in subjects' relation to the world-'ambiguity is of the essence of human existence'-Dall'Alba ([15], pp. 35-38) proposes a framework for learning professional ways of being by exploring four elements. For this author, it is about transforming ways of being with ambiguities.

First, continuity over time, with changes in the way of being a professional, occurs over time as part of our everyday life through an interweaving relationship between the past, present, and future. According to Dall'Alba ([15], pp. 38-39), although the subjects are the persons they were yesterday and will be tomorrow, they are not the same. Given that the past opens a range of possible ways of being (a range of possible development trajectories), becoming a resource in the present and future ensures continuity with change in subjects' lives. This interweaving relationship between the past, present, and future favors the development of the trajectory of subjects who, even with no prior experience, acquire knowledge (epistemology) and undergo profound changes along this journey until they become professionals (ontology). In this context, negative and positive experiences are resources for subjects to learn and improve, for instance, in 'professional education programs where aspiring professionals are prepared for practice challenges within a particular profession. As trainee teachers learn to teach, their positive and negative experiences of being students in classrooms over several years can serve as a resource for their teaching' ([15], pp. 34, 40). Another example is in an international law firm where 'the ways of practicing corporate law forms a hierarchy of competence in corporate law in the sense of an increasing comprehensiveness of ways of practicing corporate law' ([16], p. 1163). 
So, we argue that it is not only about achieving a 'final ontological state' or just 'transformations of ontology', because "learning to become a professional involves not only what we know and can do, but also whom we are (becoming) through this interweaving relationship between the past, present, and future. In the process of SLfS, it is about a dialectic ontological change since the social actors concentrate both on epistemology (knowing) and ontology (becoming) to solve sustainability issues. In this continuous dialogue, they strengthen what they already know and continue to learn and their professional ways of being and becoming. As a result, there are changes in their discourse, self-reference, and priority values.

According to Dall'Alba [15], the second element encompasses possibilities in the ways the subjects can be with constraints on those possibilities, in other words, possibilities with constraints. It means 'these possibilities are not limitless' (p. 40) and that constraints and possibilities are a double-edged sword. While there are possibilities, there are also constraints. The subject's past (history and traditions) can be restrictive, impeding the subjects from acting differently. The choice can be the well-known everydayness, routines, and regularities, which are less risky and resistant. For instance, in a professional education program, while certain practices towards transformative learning may be considered acceptable, exciting, or innovative by some students and colleagues, other practices may be regarded as inappropriate or negligent by others. So, traditional teaching practices can be both a possibility and a constraint simultaneously.

The third element is the openness to taking up possibilities and opportunities with resistance to doing so. It concerns the tensions present in both the dichotomy between innovative practices and traditional practices or innovative and preconceptions ideas in a context of power relations. For Dall'Alba ([15], p. 41), 'this struggle or interplay between openness and resistance can apply to any aspect of our relation to our world; it relates to individuals and professions as a whole. For instance, in a professional education program, 'addressing or resolving such tensions involves questioning assumptions about what teaching involves and what it means to be a teacher' ([15], p. 39). Analogously, in a SLfS process, addressing or resolving the tensions involving assumptions about producing coffee and dairy farming involves what it means to be family farmers in coffee and dairy farming.

The fourth element is the individuals who are becoming professionals through continual interaction with others involved in that process, including those outside the professions. It does not matter if they may never meet. It is the individuals with other elements. That is, being with others is to learn and act similar to them. We argue it is not an imitation; instead, it is 'taking a stand on those thoughts and actions, as well as on whom we are becoming, even if this means they simply fall into line with how 'one' should think, act and

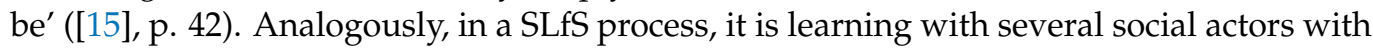
multiple interests, conflicts, and power relations, through social interactions, reflection, reflectivity, negotiating, and collaborating [1-6,9].

In line with this approach of learning professional ways of being, Sandberg and Pinnington [16] proposed a framework to understand what constitutes competence in work performance, also based on the studies of Heidegger [22]. Thus, the existential ontological perspective on professional competence is anchored in three elements: the human way of being, others in a human way of being, and things in a human way of being.

For Sandberg and Pinnington ([16], pp. 1144-1145), briefly, the human way of being is different from the being of things. It is being-in-the world. As ([15], p. 38) points out: 'central to Heidegger's ontology is his concept of being-in-the-world, which emphasizes that we are always already embedded in, and entwined with, our world, not merely contained within it'. The human way of being comes before the subject-object distinction; therefore, it should not be regarded as a subject concerning an object. Instead, the human way of being drives the subjects to 'understand themselves as particular professionals, work as consisting of specific activities, and objects as specific tools with a particular purpose' ([16], p. 1145). 
As the human way of being is being-in-the-world, competence is 'something we embody and enact in the sense of what we do and at the same time are' ([16], p. 1145). Others in human way of being means being with others. In other words, competence is socially constructed, according to the different contexts of each subject's social world, such as the professional, social, and educational. For Sandberg and Pinnington ([16], p. 1145), 'what we do and are as professionals are for the most part defined by those who we are engaged within particular human ways of being'. Things in the human way of being are the tools ranging from 'raw material to artifacts involved in human practices such as buildings, clothes, computers, copy machines and so on' ([16], p. 1145). These tools are defined by their usefulness, by their reference to other tools and by the specific existential meaning of the particular human way of being to which they belong.

In short, as shown in Table 2, although the authors have different purposes and learning processes, the proposed frameworks focus on becoming a professional and on competence as ways of being. They shared the learning process elements. For Dall'Alba [15], it is a transforming way of being comprising four ambiguities - continuity with change, possibilities with constraints, openness with resistance, individuals with others. For Sandberg and Pinnington [16], there are three elements-human way of being, others in human way of being, and things in human way of being. It is essential to highlight that the authors also share the same understanding for the elements "individual with others" and "others in human way of being".

Table 2. Becoming a professional—an ontological perspective based mainly on Heidegger's ideas.

\begin{tabular}{|c|c|c|c|}
\hline \multicolumn{4}{|c|}{ Becoming a Professional } \\
\hline Focus & Purpose & Learning Process & Learning Elements \\
\hline $\begin{array}{c}\text { Learning professional ways of } \\
\text { being-ambiguities of } \\
\text { becoming [15] }\end{array}$ & $\begin{array}{l}\text { Prepare aspiring professionals } \\
\text { for the challenges of practice } \\
\text { within a particular profession }\end{array}$ & $\begin{array}{l}\text { It involves integration of } \\
\text { knowing, acting, and being in } \\
\text { the form of professional ways } \\
\text { of being that unfold over time }\end{array}$ & $\begin{array}{l}\text { Transforming ways of being } \\
\text { with ambiguities: } \\
\text { Continuity with change } \\
\text { Possibilities with constraints } \\
\text { Openness with resistance } \\
\text { Individuals with others }\end{array}$ \\
\hline $\begin{array}{l}\text { Professional competence as } \\
\text { ways of being [16] }\end{array}$ & $\begin{array}{l}\text { Comprehensive and } \\
\text { integrative analysis of } \\
\text { professional competence }\end{array}$ & $\begin{array}{l}\text { It integrates central aspects of } \\
\text { the practice such as } \\
\text { knowledge and } \\
\text { understanding into a specific } \\
\text { professional competence in } \\
\text { work performance }\end{array}$ & $\begin{array}{l}\text { Human way of being } \\
\text { Others in human way of being } \\
\text { Things in human way of being }\end{array}$ \\
\hline
\end{tabular}

Source: The Authors, based on $[15,16]$.

Therefore, this theoretical lens is further explored below to understand how the ontological perspective can be applied to a SLfS phenomenon. Our study approaches the meaning of learning professional ways of being family farmers from an existential ontological perspective through narratives from participants' experiences, reflections, and meanings.

\section{Methods}

\subsection{Study Area and Context of the Study}

Bearing in mind that qualitative research is recommended more to understand processes and experiences of learning and transformation, as is the case with this research, the present study has a qualitative character [23]. Given the intention to understand epistemological and ontological changes, this investigation fits within the interpretativephenomenological paradigm scope [24] by a dense analysis [25] focusing on the changes in each family and in their social networks in a rural settlement. In this way, the path of SLfS is mapped [2]), identifying the participant's meanings, processes, and interactive social networks that occurred in the families' trajectory through the analysis of narratives [26,27]. 
The unit of analysis is the trajectories of 57 families that changed their status quo from landless campers to family farmers with land, from 2002 to 2011, in the Boa Vista Settlement, in Ecoporanga, Brazil, an area of 5,106,200.00 $\mathrm{m}^{2}$. In other words, the trajectories of Brazilian families who migrated from the base of the social pyramid (no income) to family farmers with land, moving up four levels in this pyramid in a decade.

On average, in the state of Espírito Santo, these families have achieved an income of seven minimum wages, monthly (R\$ 6900.00 or US\$1288.00, considering an exchange rate of $\mathrm{R} \$$ 5.36). According to The Brazilian Institute of Geography and Statistics (IBGE) criteria and Agro census [28], this income inserts them in Class B in Brazil. It is important to highlight that the Brazilian social pyramid comprises classes A, B, C, D, and E.

Class A can be thought of as upper class-more than 15 minimum wages (more than $\mathrm{R} \$ 15,675.00$ or more than US\$2924.44). Class B can be thought of as upper-middle-classbetween five and 15 minimum wages (between $R \$ 5225.00$ and $R \$ 15,675.00$ or between US\$ 974.81 and US\$2924.44). Class C can be thought of as lower-middle-class-between three and five minimum wages (between R\$ 3135.00 and R\$ 5225.00 or between US\$ 584.88 and US\$ 974.81). Class D can be considered lower-class-between one and three minimum wages (between R\$1045.00 and R\$3135.00 or between US\$ 194.96 and US\$ 584.88. Finally, class E, also a lower class whose monthly income is up to one minimum wage (up to R\$ 1045.00 or up to US\$194.96).

In Brazil, a specific group of landless people, those who have no financial means to acquire land, need to get involved in collective action to migrate from landless status to family farm owners. When this transition process takes place, it comprises three stages: (1) the formation of the landless camp); (2) settlers without regularization within the property limits. However, the settlers do not have the necessary documentation to register in government social programs, such as rural credits; (3) regularized family farmers to enjoy the government benefits, such as the following rural and housing credits: (i) initial support to buy the first tools, the first food, and some utensils to survive; (ii) credit for the purchase of small animals, seeds, seedlings for families to leverage their agricultural businesses; (iii) housing credit to build their house because their lot was empty.

Ecoporanga is one of the municipalities with the most significant number of settled families in Brazil [29]. The land stratification of small properties and smallholdings corresponds to approximately 35\% of the municipality's area. On the other hand, large and medium-sized properties represent $65 \%$ of this area, attracting people from various settlements in the region. Dairy farming and coffee farming are the basis of economic activity in this municipality, which stands out as the largest producer of milk and cattle in the state of Espírito Santo [30].

According to the latest data from the National Institute of Colonization and Agrarian Reform [29], 9374 rural settlements cover 972,289 families and 87 million hectares in Brazil. However, not everyone can migrate from the status of landless campers to family farmers.

Therefore, such a phenomenon is a SLfS because different actors get involved in interactive and iterative social networks [5] to search for a solution to a common problem [21,31]. Such networks are formed within families and other social actors such as the municipal, state, or federal government, non-governmental organizations (NGOs), landowners, and the local community. It is a slow process marked by uncertainty since the new settler will have to wait a long period to have his ideal space and become a rural producer. Therefore, there was a SLfS on two levels, epistemological and ontological.

\subsection{Data Selection}

The primary data were collected from 16 semi-structured interviews with representatives of seven families (seven interviews); representatives of two Rural Producers Associations (two interviews); the mayor of the Municipality of Ecoporanga-ES (one interview); a secretary and a technician of the Municipal Secretariat of Agriculture (two interviews); the Landless Workers Movement (one interview); the Federation of Agricultural Workers of the State of Espírito Santo (one interview); the Capixaba Institute of Research, Tech- 
nical Assistance and Rural Extension (Incaper) (one interview); the National Institute of Colonization and Agrarian Reform (Incra) (one interview).

A priori, the rationale for sample selection, followed the criterion of representatives from different social actor' categories involved in this SLfS process: families, public bodies, and social movements. Consequently, the family associations emerged from the interviews, being included as a posteriori.

Secondary data are from various public documents available on public agencies' websites, such as reports on the technical assistance and rural extension program, settlement legislation, accountability reports, reports from the settlement's family association, news in the media. The rationale for document selection followed the criteria of the subject: settlements in Brazil and Ecoporanga.

The main questions for all interviews were: 'How did you start your involvement with the Boa Vista settlement?', What is your involvement currently?', 'Who are the social actors involved in this settlement?', 'What are their roles and responsibilities?', 'What are the main actions in course happening in the Boa Vista settlement'?, 'What are the needs of this settlement'?, 'What has this settlement achieved'?, 'How do you dialog/interact/negotiate with the other social actors?'. Two additional questions were asked for families: 'What have you learned over the period involved with the Boa Vista settlement'? 'How have you learned over this period?'. Of course, throughout the interviews, other questions were asked to understand the interviewees' experiences, reflections, and meaning in a detailed way.

\subsection{Data Analysis}

The data were analyzed using thematic narrative analysis [26] based on the combination of four distinct narrative construction processes: (i) persuasion-through the explanation of theoretical supports, as well as the use of alternative modes of analysis of data, the text assumes a convincing character; (ii) correspondence- the texts are constructed based on the comments of the study participants and emphasized after reading all the materials that were collected, such as interviews, letters, and other interpretative texts; (iii) coherence: observing the coherence of the narrative globally (the objectives that the narrator wants to achieve with the story he tells), local (the places where the action takes place) and thematic (the content of what is analyzed); (iv) pragmatic use of the narrative - the researcher must keep in mind that a particular study may form the basis for further work. For this reason, providing complete information regarding data collection and interpretation is an important activity to understand the stories and narratives of the actors involved in the SLfS process.

For Riessman [26], those who read the instruments, in a certain way, imprint their experiences and references in this analytical process. Therefore, they give new meaning to the text, using common sense values and discourses in a particular culture. For this reason, Riessman [26] explains several ways to develop a narrative (tell a story) since it is intrinsically related to the data and the local context, which can suppress or encourage both interviewees and the interviewer to interpret it in different ways. Among the types of narratives proposed by this author-thematic, structural, and dialogic narratives-it was chosen to apply thematic analysis in this study since it aims to identify the communicated content, that is, 'what is told', and not 'how it is told' or 'to whom it is told', 'when it is told' or 'why it is told'. In other words, this research sought to tell stories about how the process of social learning for sustainability facilitates the transition from landless workers to family farmers.

For this reason, the temporal and spatial experiences and information of the narratives of the various social actors of the Boa Vista Settlement were prioritized. Thus, 12 themes were generated that capture the meanings of the social actors who experience this SLfS process, with both defined a priori, that is, from the studies of SLfS and the field data, namely: the triggering factor of the problem; the network of relationships within families and among other public and private social actors; conflicts; settlers' needs; power relations 
involved; dialogues, negotiation, and interaction; social learning spaces for sustainability; support from leaders of NGOs already well established in the country; set of rules and guiding instruments; standard view of the family group; a sense of belonging and emotional involvement of families and other social actors; financial and technical support from the government; a network of favorable political, economic, and social conditions in the state of Espírito Santo, Brazil.

From this analysis, three grand narratives emerged from the participants' experiences, reflections, and meanings based on their trajectory of SLfS. The researchers constructed the narratives based on the timeline of families' trajectory. That is, a specific group of landless people, those who have no financial means to acquire land, need to get involved in collective action to migrate from landless status to family farm owners. When this transition process takes place, it comprises three stages: (1) the formation of the landless camp); (2) settlers without regularization within the property limits. However, the settlers do not have the necessary documentation to register in government social programs, such as rural credits; (3) regularized family farmers to enjoy the government benefits.

\section{Results}

\subsection{Family Farmers and Other Social Actors' Narratives of the SLfS}

In the first part of this section, we present three narratives to show how the process of SLfS facilitates the transition of Brazilian families who were at the base of the social pyramid (no income) to a change of status from landless campers to family farmers, moving up four levels in this pyramid over a decade. The narratives are (1) before becoming a rural producer, you need to camp in the canvas tent on the asphalt edge; (2) now, sitting on the property, but still without land ownership; (3) finally, family farmers in coffee and dairy farming.

The third part of this section analyzes a SLfS process's ontological aspects from the existential ontological perspective elements to understand the professional learning ways of becoming family farmers.

4.1.1. Before Becoming a Rural Producer, It Is Necessary to Camp in the Canvas Tent on the Asphalt Edge-Narrative 1

According to family farmers, the camping process in canvas, bamboo and plastic tents is part of their efforts to improvise housing on the side of the road, outside the boundaries of the desired property, which would still be granted/expropriated by the National Institute of Colonization and Agrarian Reform (Incra) through the agrarian reform program of the federal government.

Non-governmental organizations guide these families as social movements (the Landless Workers Movement and the Federation of Agricultural Workers of the State of Espírito Santo), who act after identifying unproductive land. These organizations pressure the government at the municipal, state, and federal levels for more public settlement policies and a faster land expropriation process. According to the Incra public servant:

There would be no expropriation of the areas if there were no social movements because public servants' time is different from the citizen's time.

On the side of the road, although the families faced several challenges, including scarcity and deprivation of resources, to achieve their goals, the church (it does not matter the religion), non-governmental organizations, or government support them with water, canvas, and parcel food. These conditions are illustrated in the statement of settler \#3:

Ah, first, we came under the canvas tents. Then we stayed on the side of the road. I cooked on a wood stove, fetching water from the stream, which was far away. Our food was the heart of palm because we had nothing to eat, a tent made of bamboo, a firewood furnace. Nobody had gas; nobody had light. Our lamp was diesel oil. All this suffering went on until we got the land (settler \#3). 
For Jacobi et al. ([32], p. 7), a social learning process for sustainability (SLfS) is triggered by recognizing and explaining conflicts originating from environmental issues, understanding the environment as a public good, and access to a healthy environment as a citizenship right'. Analogously, in settlement of our study, the SLfS process was triggered after the emergence of conflicts that originated from social issues. In Brazil, a specific group of landless people, those with no financial means to acquire land, need to get involved in collective action to change the status from landless to family farmers. These families, who are at the base of the pyramid (no income) and have difficulties meeting basic needs, started a social learning process to struggle for land to become self-sustaining.

Then, the desired land acts as a trigger for the beginning of the SLfS and becomes a source of conflict among economic and social actors within the community increasingly. Conflicts, such as psychological and physiological conflicts, had to do with their social condition and regarded lack of food, water, and shelter. The screening of families to participate in this social learning process also generated conflicts among families, as not all of them had an agricultural tradition. A few families infiltrated the camps and, despite being in search of an opportunity for other gains, the movements later accepted them, according to a public servant from Incaper. Another conflict was the land choice which would still be granted/expropriated by (Incra). According to settler \#6, the public bodies did not use rigorous analysis criteria on fertile land for plantation. He said:

Not everything you plant will flower. In my land, there are some areas where it is not possible to plant. For example, I tried to plant grass-fed animals, sugar cane, and cassava, but I was unsuccessful.

The two social movements are 'water and oil; they do not mix', according to the Ecoporanga Agriculture Department civil servant. Although they have the same objective, social transformation, their ideological identity is different, reflecting their struggles. Often, they use different forms of rights and obligation negotiations for the families. There are also differences in how they manage the pressures related to the agrarian reform process, said one of the leaders of the social movements.

The landowners, neighbors of the camps, were concerned due to the rapidly rising number of people from different regions on the road's side near their properties. These farmers were against the social movements, even using violence to restrain the encampments' advance.

Therefore, it was a period of resistance testing, uncertainty, and learning for these families, focusing on collaborative and mutual support networks. They learn through participation, engagement, and social interaction. They focused on continuous dialogs, collaborative and mutual support networks with the other families, public bodies, churches, and social movement organizations. Therefore, they also learn through negotiation with these organizations to deal with the conflicts.

About these conflicts, the public servant from Incra said:

Every day we learned something, especially having patience and negotiation abilities. We learned about persistence and transparency.

At this stage, the camped families were registered with Incra, a necessary condition on their path to becoming rural producers. In addition, Incra maintains a database with several studies referring to Brazilian properties, whether productive or not, resulting from constant surveys on rural properties' conditions. However, when there is a camp of landless workers, the survey is prioritized.

The Boa Vista settlement resulted from negotiating a property located two kilometers from the families' camp. According to an Incra's public servant, this negotiation initiated with the owner's offer to the government, following Decree No. 433/92 [33]. After evaluating the property as unproductive and a counterproposal from the landowner, the agreement was closed. The bare land was paid in agrarian debt bonds within five years, and the improvements made by the landowner were paid in cash. This act was endorsed at a public hearing held in the municipality of Ecoporanga. 


\subsubsection{Now, Sitting on the Property, but Still without Land Ownership-Narrative 2}

After approximately two years living on the side of the road, outside the boundaries of the desired property, the families finally moved to the expropriated land. Thus, it is the beginning of the settlement process within the boundaries of their future property. Here, the first action is the lot's demarcation and distribution to families by Incra. This condition is explained by settler \#4:

We camped to acquire a piece of land at the edge of the asphalt. Then, Incra informed us that the land had been negotiated and we could move to the property. Nevertheless, in the lots assigned to each family, they had not yet done either the topographic survey or the exact division of areas.

The lots were measured and drawn among the families and, if the location did not please, the lots could be exchanged with the other families. Thus, a property of 5,106,200 $\mathrm{m}^{2}$ was distributed to 57 families, each with an area of $72,600 \mathrm{~m}^{2}$, leaving a protection area of $968,000 \mathrm{~m}^{2}$. Each lot can house up to two families if their children want to remain on the property.

After this period of distribution, negotiation, exchange, and the adaptation of each family in their due lot, the stage of regularization of ownership of the property begins, in order to obtain government benefits, such as the following rural and housing credits: (i) initial support to buy the first tools, the first food, and some utensils to survive; (ii) credit for the purchase of small animals, seeds, and seedlings for families to leverage their agricultural businesses; (iii) housing credit to build their house because their lot was empty. This process is slow and marked by uncertainty since the new settler will have to wait for a few months to have his space. For example, settler \#10 reports that she received her lot and waited to regularize ownership to start her farming with others' help. During this transition period, the focus is on subsistence agriculture- the families grow food crops to meet their needs.

Also, at this stage, it begins the families' adaptation to the surrounding population and the infrastructure operationalization with the Ecoporanga Agriculture Secretariat, the Capixaba Institute for Research, the Technical Assistance and Rural Extension (Incaper), and Incra support. The two public bodies were involved in guiding and assisting families in obtaining rural worker qualification documentation. The children start attending municipal schools, creating bonds in the region.

They form two associations, which emerge from the two social movements, to maintain and gain families' rights in their governance. So, another conflict the families had to deal with inside in one of the Rural Producers Associations. One of them is suspended due to internal conflicts between managers, discouraging meetings with families. In both, said settler \#8:

The dispute for power among their members often generates conflicts of interest (nonagreement in selecting government aid programs and personal problems) between some families and associations.

Also, the two Associations need to join forces to negotiate together, increasing their negotiation power with the other social actors.

This second stage lasted for approximately one year.

\subsubsection{Finally, Family Farmers in Coffee and Dairy Farming-Narrative 3}

In the third stage, with the documentation fully regularized, the settled families advance in the process of becoming family farmers, ceasing to be landless rural workers, as they now have their land. For Incra, it is not enough to hand over the land to the settler if there is no support for follow-up and guide the new owner to become a family farmer. According to the public servant:

Incra's responsibility is to provide for the socio-economic development of these familiesocial inclusion, respect for production, education, infrastructure, commercialization, 
and technical assistanc-until their consolidation and insertion in the community and society of the municipality.

Incra counts on the municipality's support, which invests in education, infrastructure, health, and drainage, as these new businesses contribute to circulating the region's economy.

Families begin to experience new challenges, such as subsistence. It is a time when these producers will require skills that have not been demanded until then, as workers (employees), such as entrepreneurship, technical knowledge, soil management, and use of technologies. From an epistemological point of view, the SLfS of some families is based on observation and experience. Therefore, it is possible to say that the Boa Vista Settlement by itself is configured in a SLfS space, which occurs naturally and gradually, from observation, exchange of experiences and replication of practices among the various social actors.

According to Bouwen and Taillieu ([2], p. 147), 'multi-party collaboration projects are the social space par excellence where codified scientific knowledge and practitioners knowledge are merged'. For them, transitional space is 'a meaningful space for acknowledging different understandings and a social space acknowledging each other's presence and identity' (p. 150). So then, knowledge is multiplied, according to a representative of one of the social movements and the settlers \#1, \#4, and \#7, showing how this SLfS occurs and its outcomes:

'[...] I was a layman in coffee-growing; I didn't know anything. Many people asked me, how do I do such a thing, if you don't know ... For example, prune a coffee tree. I said I ask! Then, they would look at me and ask: Aren't you ashamed? I said, no, I'm learning! Thank God, it works because I copy everyone who really knows, I copy, and they also encourage me' (Settler \#1).

Rural producers seek to mirror themselves much more in other colleagues than in technical guidance. They learn more by seeing and hearing how it is done. Regardless of where family farmers are organized, they are mirrored in other struggles, work, and production experiences. According to settler\#4:

'When we leave home, we see what the other does. Then, you pass on the experience to the other. They inform us where there is a lecture for us to attend-few families go. We get to know and understand how it works. Sometimes an outsider comes, and we exchange ideas and that way, we learn (Settler \#4).

[...] when I came into the land, I did not know what it was like to tie a sieve around my waist. When I got coffee, I bought two sieves and watched my colleague tie the sieve, so I could learn how to tie it, I just looked and did it. I picked the coffee straight, their way. There was no problem, I didn't break a branch or anything. Then, to sprout and prune the coffee, I went to look at my colleague to see how he did it. I got there, looked at how he did it and went to work at my cafe. Incra also sent a technician to teach us how to work on the land. Since then, we are ready! Today, we know how to work (Settler \#7).

The SLfS in this settlement is similar to all other social learning experiences in agriculture since agriculture itself is a social learning space. For instance, Phuong, Tuan e Phuc [12] showed that transformative social learning focuses on instrumental learning (rules and channels), communicative learning (interactions to share practical learning), and emancipatory learning (self-decision of learners and their beliefs on technology, within their social systems of learning) in a production ecosystem—garden/orchard, fishing and livestock, farm and biogas-in Vietnam.

In an organic agriculture cooperative in Spain, Ríos et al. [34] showed that formal knowledge networks include workshops, courses, meetings, and agreements with external institutions. Autonomy allows the learners to be more flexible and adaptive before challenges, opportunities, and problems. All these features contribute to rural prosperity.

It is possible to observe that SLfS also occurs from relational practices-'any interactive project or exchange between at least two actors; it has a consequence for the relationship and some perceivable outcome. Simple concrete examples of a relational practice are a joint 
field visit, a common training session or simulation, a project starting event, a moment of spontaneous celebration, but also an open interview, a good conversation, or an open constructive meeting' ([2], p. 144) between families and public bodies.

For instance, Incra and Incaper are responsible for supporting and teaching new farmers to deal with pests and diseases in crops and organize and formalize selling agricultural products or livestock milk production. Tran et al. ([12], p. 31) also showed that social learning through informal networks and communication 'plays a significant role in facilitating the adoption and dissemination of experiential and experimental knowledge, especially across geographical boundaries in rural communities in Vietnam.

Public bodies also continue to support the families in a tailored way to obtain new financial incentives. For example, the Incaper public servant explains:

We support families in the agricultural area, specifically in issuing documents and reports to funding coffee farmers' activities and the National Rural Housing Program. For example, when someone comes and says, 'there is a plague in my field, I need a technician to visit it', the technician goes to the property. We also have the zootechnician to assist the farmers in dairy farming, another branch of the settlement. As coffee producers, we try to do a job on the importance of these settlers issuing the production invoice. Often, they are unable to prove an income because they sell what they produce without an invoice. So, we have been doing individual work with each family.

The settler \#3, when asked if she learned anything about sustainability, says that she learned to use organic fertilizer from fruit peels and food scraps and that she no longer uses pesticides in her garden:

I learned a lot. I did not know how to plant a garden; today, I know how to plant. I know how to make organic manure, which many people do not know how to do, and I have already learned. I do not use these poisons on my plants. Incra also taught how to plant trees with gel in a dry place, where there is no water, to fertilize, thinking about sustainability. Those who were interested learned. Because there is much lack of interest and the person who must be interested, if not interested, learn nothing'. Today, I perform as I should, and I don't disappoint myself.

Some become entrepreneurs and begin to generate jobs, contributing to the region's economic transformation, as reported by the Municipal Secretary of Agriculture:

There are those guys who have a more entrepreneurial outlook. There is one who wants to produce more. He has already reached a level of development so great that he already wants to have his dryer; he wants to have his coffee machine. We already have some settlers who already pay for labor. He hires labor from state settlements. So, inside the settlement structure that reached the wall, he wants to jump over the wall; he wants to go further. So, this individual who has this vision ..., is ... I will be bold to say: this more excellent entrepreneurial vision, so this settler has already gone to another level of development. So, he already has thought beyond his reality. He has already reached the development level so great that he no longer wants a hectare of coffee. He's already planted two, got it? He's already paying for labor.

\subsection{Learning Professional Ways of Being Family Farmers}

Following the existing ontological perspective dimensions, this section analyzes the specific ways of becoming family farmers. In the first narrative, camping in canvas, bamboo, and plastic tents on the side of the road, outside the boundaries of the desired property, is a process of suffering and difficulties that legitimizes the families' lives struggle. It provides them with a new identity, and it is the base for initiating the transformation of their selves. At this stage, they begin to understand themselves as camped landless workers.

Therefore, this transformation self-process meant incorporating the routines and traditions of being a camped landless worker in canvas, bamboo, and plastic tents on the side of the road. It is a tradition that originated in the 1960s in Brazil. This tradition was evident in the settlers' discourse regarding the motivation to face the process of camping in 
the canvas tents regarding expectations of life change and social inclusion. 'On canvas tents, life is crazy', said settler \#2, 'but it was worth it', added settler \#3.

On the other hand, the specific activities from this camping on a canvas tent are registering camped families at Incra, negotiating the property and several conflicts. They are the specific understanding of the work done in this first stage SLfS process. Two specific groups of strategies were necessary to accomplish this objective: creating pressures with social movements and supplying resources since, during this period, the families did not engage in paid activities. Hence, the others in human way of being are the several social actors-Incra, social movements, city hall of Ecoporanga, the churches, who support the families throughout the SLfS process differently. All the social actors involved in this SLfL process are in Figure 1.

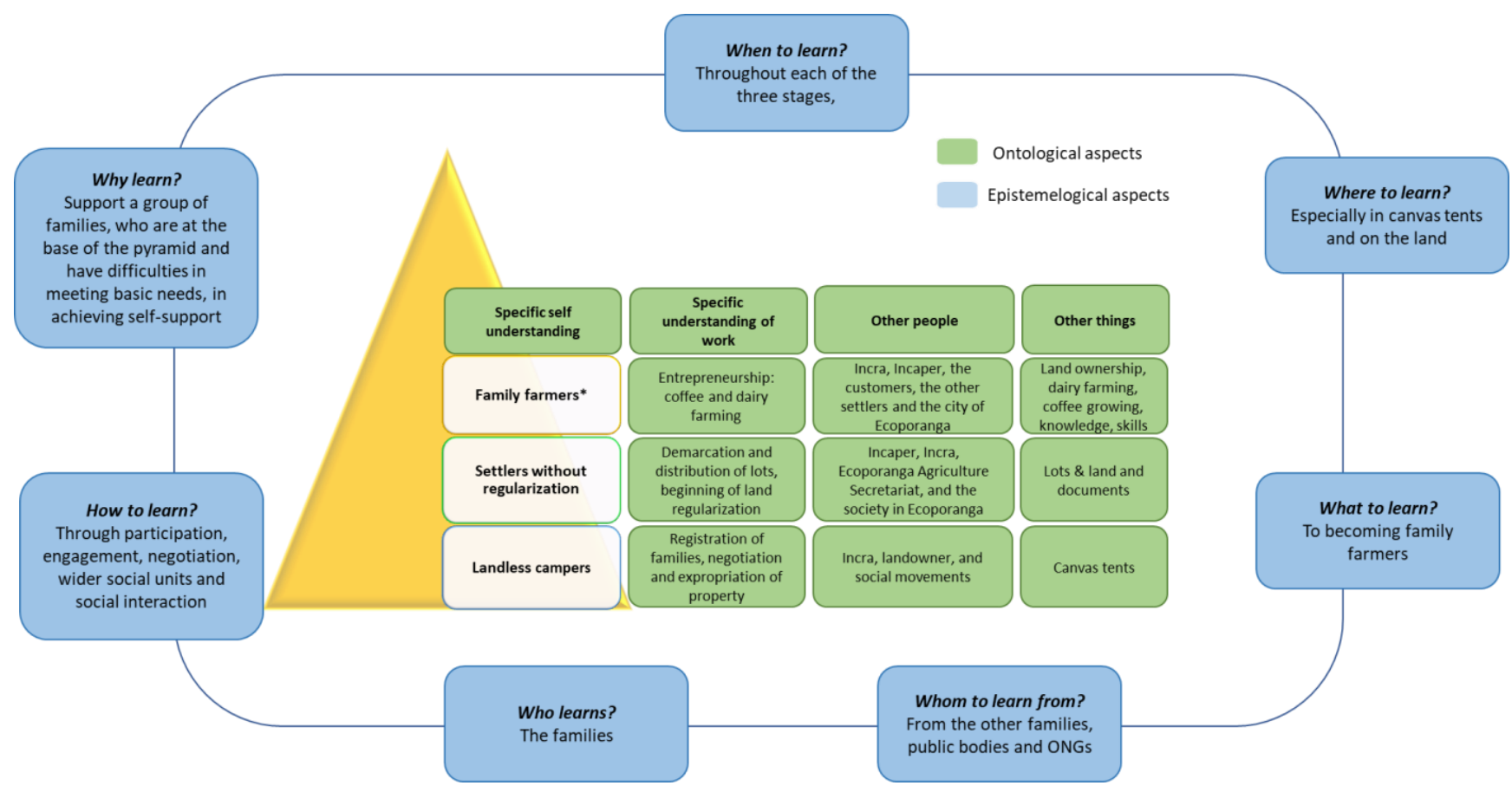

Figure 1. Elements of the SLfS process of family farmers. Source: The Authors.

The primary tool used is the canvas tent, which has a specific existential meaning of the human way of being in this first stage for the families. The tents were essential to obtain their plot of land and become, later, family farmers. The tents meaning for becoming family farmers are their struggle and efforts to obtain the desired plot of land in a property. As illustrated in the statement of settler \#7:

Look, my struggle to get to the Boa Vista settlement was due to my efforts to stay under the canvas tent, where I was from 2001 to 2004. Then, from 30 December 2004, I became a settler (settler \#7).

Becoming a settler but still without land ownership meant they transformed themselves since they changed their identity. They understood themselves as settlers meant the activities that consist of the specific understanding of work in this second stage concern the demarcation and distribution of the lots, the property regularization to obtain the government benefits, and adaptation of these families to the surrounding population. The other social actors are Incaper, Incra, Secretariat of Agriculture of Ecoporanga, the Capixaba Research Institute and the society in Ecoporanga. At this stage, the primary tools are the lots, as they denote land ownership and documentation, as it is helpful to get rural and housing credits to start subsistence agriculture.

Being a rural family farmer (3rd stage)—is the target social identity. The families' selves are understood and transformed into economically active people. In other words, 
they assume a new status quo-family farmers with income; some of them are starting to generate new jobs. This change in status is also revealed in the recovery of these rural producers' citizenship, a sense of belonging based on a set of rights and obligations in putting into practice the social project of becoming rural producers. They can fully exercise their citizenship because their civil, political, and social rights are also guaranteed in addition to their obligations. Settler \#4 reported:

\section{It is a huge step forward-getting out of the canvas tent and into a house with adequate} infrastructure. It is a substantial change!

Throughout this process, families shared a vision-to get out of extreme poverty and become family farmers, which weaken the difficulties encountered during the camp's transition and in the final stage of this SLfS process. It is the driving force of this movement, and, therefore, it is agreed that a small win by a resident represents a lot for the entire settlement.

Despite the difficulties and conflicts, the Boa Vista Settlement families share stories of overcoming, being a reference for 'prosperity' multiplied among the other settlements in the region by the Municipality, State, Incra, Incaper, and being a point of pride for the residents and the association. This prosperity has been justified by producing food and inputs that have quantitatively placed the settlement in a prominent position among the others, leaving the Boa Vista Settlement in evidence concerning the other settlements in the region. Here, it is observed that SLfS occurs at the wider social units or communities of practice through social interaction and processes between actors within a social network, as advocated by Reed et al. [5].

Based on these social actors' perspectives, they managed to move up in the Brazilian social pyramid because, throughout this process, they got small wins. It 'is a controllable opportunity of modest size that produces visible and tangible outcomes' ([2], p. 141) from the first moment. Nevertheless, first, gain social movements' support and technical and financial support from the municipal, state, and federal governments. Being the basis of support for these families, who struggle to reach the dreamland, today, the rural producers are the ones that contribute positively to the municipality's indexes' growth.

The Boa Vista Settlement is producing and generating favorable results for its residents and the local economy. In other words, there is a transformative social learning process in the municipality of Ecoporanga involving multiple social actors. The settlers' activity is essential for the local economy regarding food production and financial increases related to the resources obtained by various credit lines invested in the municipalities' trade. When the settlement process begins, the municipality also undergoes a transformation process, as it will have to adapt and, in some cases, restructure itself to receive new families. This process involves economic and social issues so that the municipality starts to develop new public policy structures to support these families.

The social support for settlements is justified, above all, by the municipality's interest in the return on investment through the development of the settlement that collaborates for the local economy, by generating a source of revenue for the municipality such as income, employment, food production, and fighting rural exodus.

In the narratives of the municipality's interviewees, support for agrarian reform projects was evidenced. The municipal manager expressed that the settled families are essential for the local impact of the municipality's economy, claiming that the municipal situation would worsen if it were not for the settlements. These settlements return the citizens to produce in the countryside, generate income and employment, besides helping combat the rural exodus suffered in the 60s, 70s, and 80s.

Given the above, others involved in learning this professional way of being family farmers are mainly Incra, Incaper, the customers, the other settlers, and the city of Ecoporanga. The primary tools are land ownership, dairy farming, and coffee growing by its meaning along this trajectory of SLfS and the knowledge and skills by its usefulness, which are being learned, including in sustainable practices to become family producers.

Table 3 summarizes the other social actors and their interests. 
Table 3. Social actors' interests.

\begin{tabular}{|c|c|c|}
\hline \multicolumn{2}{|c|}{ Social Actors } & Interest \\
\hline Families & $\begin{array}{l}\text { Camped } \\
\text { Settled } \\
\text { Rural farmers } \\
\text { Associations }\end{array}$ & $\begin{array}{l}\text { Search for land } \\
\text { Search for regularization } \\
\text { Coffee and dairy farming producers } \\
\text { Support for families }\end{array}$ \\
\hline Public bodies & $\begin{array}{c}\text { Incra } \\
\text { Incaper } \\
\text { City Hall of Ecoporanga }\end{array}$ & $\begin{array}{l}\text { Land negotiation, technical support for regularization } \\
\text { Technical support for plantation } \\
\text { Infrastructure support for the families, generating } \\
\text { income from projects for agrarian reform. }\end{array}$ \\
\hline Social movements & NGOs & Guide and defend the families in the search for land \\
\hline Local community & Local commerce, churches and schools & $\begin{array}{l}\text { Social Integration, generation of temporary } \\
\text { labor, education }\end{array}$ \\
\hline
\end{tabular}

Source: The Authors from research data.

At this point, it is possible to observe that the existential ontological perspective dimension-others in human way of being or individuals who are becoming professionals with others-is an intersectional element with collaboration, participation, engagement and negotiation dimensions of SLfS [1-8].

\subsection{The Ambiguities of Learning Professional Ways of Being Family Farmers}

Throughout the learning, professional ways of being can create ambiguities regarding continuity over time with change, according to Dall'Alba [15]. Analogously, in this study, it is a journey of families, in which most of them have little or no knowledge or experience with farming, but through positive (i.e., advancing from canvas tents on the asphalt edge to being settled in lots, accessing rural and housing credits) and negative (i.e., scarcity and deprivation of resources, insecurity, and conflict with landowners against social movements, even violence being used to restrain the advance of the encampments) experiences, have faced profound changes and acquired knowledge until they become coffee and dairy farmers.

The small wins [2], in each stage, are a path dependence from past and present to trigger changes in the future continuously. For instance, besides becoming farmers, they also learn sustainable farming practices. It refers to the ambiguity regarding openness and opportunities with resistance [15]. In other words, they are learning innovative practices despite the traditional ones (i.e., organic manure vs. poisons on the plants or plant trees with gel in a dry place).

Despite the possibilities discussed above, these families have also faced constraints. For instance, not all families become entrepreneurs and generate jobs. Many families decided to plant for their self-sustain. It can be interpreted that the subjects' past-no income, no land, no place to live-is acting as a restrictive factor. For Dall'Alba [15], it is about the ambiguity regarding possibilities with constraints.

\section{Discussion}

\subsection{Learning Professional Ways of Being Family Farmers}

From an epistemological perspective, a SLfS facilitates aspiring farmers to become family farmers (what to learn) because they are at the base of the pyramid and have difficulties meeting basic needs and self-sustain (why learn). According to Ríos, Rivera, and Garcia ([34], p. 92), social learning contributes to rural prosperity by 'fulfilling the needs of the people to get involved in the territory generating a sense of belonging, participating and working together'.

The families (who learn) learn through participation, engagement, negotiation, and social interaction based on continuous dialogs, collaborative and mutual support networks with the other families, public bodies, churches, and social movement organizations (whom to learn from), especially to deal with the several conflicts throughout this SLfS. It means a 
change in the subjects' understanding involved in this SlfS and understanding on a broad scale, according to Reed et al. [5], since the settled families are essential for the local impact of the municipality's economy, claiming that the municipal situation would worsen if it were not for the settlements. Ecoporanga is one of the municipalities with the most significant number of settled families in Brazil [29]. So, the learning also occurs within wider social units (how to learn) [5].

Therefore, the social spaces, mainly the canvas tents, land, and the relational practices [2], through visits, training sessions, meetings, informal conversations, are part of becoming family farmers (where to learn).

Since in Brazil, a specific group of landless people, those who have no financial means to acquire land, need to get involved in collective action to migrate from landless status to family farm owners, they follow a process which comprises three stages: (1) the formation of the landless camp); (2) the moving within the property limits; (3) becoming regularized family farmers. Therefore, the SLfS occurs throughout these three stages, each with its idiosyncrasies, as discussed above (when to learn).

From an existential ontological perspective [15,16], learning professional ways of being family farmers in SLfS in this study means:

A specific self-understanding (being landless campers, settlers without regularization and family farmers) and a specific understanding of work (registration at the legal office, negotiation and expropriation of property, demarcation and distribution of lots, land regularization and entrepreneurship on coffee and dairy farming), through continual interaction with other professionals (landowners, social movements, Incra, Incaper, Agriculture Secretariat, society), using tools due to their usefulness and meaning (canvas tents, lots, land and documents, land ownership, dairy farming, coffee growing, knowledge, skills), dealing with ambiguities and taking advantage of the negative and positive experiences over time.

Figure 1 summarizes a SLfS process from three narratives describing the epistemological aspects and emphasizing social learning's ontological aspects.

\subsection{Implications for SLfS Literature and Contributions}

By analyzing and describing how the process of SLfS facilitates the transition of Brazilian families who migrated from the status of landless to family landowners, it presents both methodological, theoretical, and practical contributions. From the point of view of methodological implications, the results show the contribution of the existential ontological perspective $[15,16]$ to the SlfS studies. Furthermore, it contributes to perceiving how the driving forces of learning professional ways of being and its ambiguities are significant and can help understand how landless families become rural farmers.

For SLfS theory, the investigation intends to advance the ontological level discussion, going beyond the epistemological elements-what to learn, how to learn, who learns, whom to learn from, when to learn, and where to learn. It starts to observe the impacts of the learning cycles in the resignification of the identity of the being, in this case, in constructing families' identity as rural producers.

It is a matter of discussing how to support families at the pyramid base who have difficulties meeting their basic needs. Thus, it contributes to covering the demand for more research in SLfS, focusing on the social dimension [17].

So, it proposes to discuss the ontological aspects relating to who social actors are becoming in a SLfS process: learning professional ways of being family farmers based on the frameworks of Dall'Alba [15] of professional competence as ways of being by Sandberg and Pinnington [16]. In this research, ontological thinking involves preparing aspiring farmers, emphasizing that most of these people are illiterate or have only primary education for the challenges of practicing dairy farming and coffee growing professionally. In other words, the evidence shows that these families went through three distinct moments in this process of SLfS to learning professional ways of being family farmers: being camped in canvas tents, being settled in lots and, finally, being family farmers. Such moments-past, 
present, and future-favor acquiring and developing knowledge while molding a new identity - a new identity and becoming part of a social world distinct from the previous one. They assume a new status: family producers with their income; some are already starting to generate new jobs.

The negative and positive experiences, mainly the conflicts, also contribute to these families' learning and improvement, as Dall'Alba [15] argued. It is essential to highlight that it is a transformative social learning process in the municipality of Ecoporanga, involving multiple social actors and based on small wins [2], at each advancement in the trajectory, through continuous dialogues with the network of participants. As a result, the Boa Vista Settlement generates favorable results for its residents and the local economy.

Therefore, studying these families' trajectories also contributes to the research in SLfS in a different socio-ecological system [5,18]. Many studies have discussed social learning in several social-ecological systems, such as an organic agriculture cooperative [34], in a production ecosystem - garden/orchard, fishing and livestock, farm and biogas [12], in a forestry and salmon farming [18], in rural communities [8], and so on. In our study, social learning is applied to a group of landless workers with idiosyncrasies (long trajectory to become rural producers) little discussed in SLfS literature.

Finally, this experience can be applied to similar socio-economic contexts where there are high rates of land inequality and rural grievances to advance and accelerate successful experiences of becoming a farmer in low-income regions, mainly in South America, South Africa, and Asia.

In South America, for instance, in Peru, Albertus ([35], p. 17) demonstrated that land reform could impact civilian organization, which is critical in fighting guerrillas [ ... ]. This author also demonstrated that 'because land reform is a transformational social and economic policy, it can have profound political effects on the constraints and opportunities guerrillas face regarding resources and recruitment'. Albertus and Kaplan [36] showed a similar impact, in Colombia, that land reform reduced guerrilla activity, despite being politically challenging to implement at a sufficient scale because it threatens elite interests.

In South Africa, although there is Vision 2030 and the National Development Plan for land reform [37], Hall e Keep ([38], p. 8) found evidence on land reform that elite capture and state neglect. It is 'a two-tiered land reform in which some (white-owned) agribusinesses garner handouts from the state. In contrast, low-income families and communities who have accessed state land are left with insecure tenure and livelihoods'.

\section{Conclusions}

This study analyzes and describes how the process of SLfS facilitates Brazilian families who were at the base of the social pyramid (no income), to change the status from landless campers to family farmers, moving up four levels in the social pyramid over a decade. So, we identified the SLfS elements encompassing the epistemological arena-what to learn, how to learn, who learns, whom to learn from, when to learn, where to learn, and why to learn-professional ways of being family farmers.

By doing that, our focus goes beyond the knowledge as an end in itself in SLfS. Instead, we discuss how these elements can be a solid foundation for who the families are becoming. We did this discussion anchoring on frameworks of Dall'Alba [15] and Sandberg and Pinnington [16] of learning professional ways of being - specific self-understanding, a specific understanding of work, continual interaction with other professionals, and using tools due to their usefulness and meaning.

Therefore, this study discusses the contribution of the existential ontological perspective to the SLfS theory. Furthermore, it is a starting point to advance the discussion on ontological aspects of SLfS, beyond its epistemological aspects, the focus of most literature in this field. Thus, future research can expand the ontological framework empirically to other socio-ecological systems in other countries.

As a limitation, there is not a comparison between a successful and an unsuccessful way of becoming family farmers. Some settlements have been faced with problems in 
assisting families to become family farmers. Future studies can extend the discussion for these groups of families in other settlements.

Author Contributions: Conceptualization, M.J.d. and J.M.T.; Formal analysis, J.B. and J.M.T.; Funding acquisition, M.J.d.; Investigation, J.M.T.; Methodology, M.J.d.; Supervision, J.B.; Writing—original draft, M.J.d.; Writing-review \& editing, J.B. All authors have read and agreed to the published version of the manuscript.

Funding: This research received no external funding.

Institutional Review Board Statement: Ethical review and approval were waived for this study because it follows the guidelines of the Brazilian Resolution $\mathrm{n}^{\circ}$ 510, of 7 April 2016 (http:/ / conselho. saude.gov.br/resolucoes/2016/Reso510.pdf).

Informed Consent Statement: Informed consent was obtained from all subjects involved in the study.

Data Availability Statement: Data Availability Statements in Portuguese with the Authors.

Conflicts of Interest: The authors declare no conflict of interest.

\section{References}

1. Craps, M. Social learning in River Basin Management. HarmoniCOP WP2 Reference Document. 2003. Available online: https://www.harmonicop.uni-osnabrueck.de/_files/_down/SocialLearning.pdf (accessed on 14 July 2020).

2. Bouwen, R.; Taillieu, T. Multi-party collaboration as social learning for interdependence: Developing relational knowing for sustainable natural resource management. J. Community Appl. Soc. Psychol. 2004, 14, 137-153. [CrossRef]

3. Keen, M.; Brown, V.; Dyball, R. Social Learning in Environmental Management: Towards a Sustainable Future; Earthscan: London, UK, 2010.

4. Pahl-Wostl, C.; Craps, M.; Dewulf, A.; Mostert, E.; Tabara, D.; Taillieu, T. Social learning and water resources management. Ecol. Soc. 2007, 12, 5. [CrossRef]

5. Reed, M.; Evely, A.C.; Cundill, G.; Fazey, I.R.A.; Glass, J.; Laing, A.; Newig, J.; Parrish, B.; Prell, C. What is social learning? Ecol. Soc. 2010, 15, 1-10. [CrossRef]

6. D'Angelo, M.J.; Brunstein, J. Social learning for sustainability: Supporting sustainable business in Brazil regarding multiple social actors, relationships and interests. Int. J. Sustain. Dev. World Ecol. 2014, 21, 273-289. [CrossRef]

7. Brunstein, J.; Jaime, P.; Curi, D.P.; dAngelo, M.J.; Mainardes, E.W. Assessment and evaluation of higher education in business management: An analysis of the Brazilian case in the light of social learning theory for sustainability. Assess. Eval. High. Educ. 2015, 40, 833-854. [CrossRef]

8. Tran, T.A.; James, H.; Pittock, J. Social learning through rural communities of practice: Empirical evidence from farming households in the Vietnamese Mekong Delta. Learn. Cult. Soc. Interact. 2018, 16, 31-44. [CrossRef]

9. Notaroberto, L.; d'Angelo, M.J. Employability of the disabled people: A Brazilian case in the light of the theory of social learning for sustainability. Int. J. Hum. Resour. Manag. 2020, 20, 295-321.

10. Van Epp, M.; Garside, B. Towards an evidence base on the value of social learning-oriented approaches in the context of climate change and food security. Environ. Policy Gov. 2019, 29, 118-131. [CrossRef]

11. Cincera, J.; Biberhofer, P.; Binka, B.; Boman, J.; Mindt, L.; Rieckmann, M. Designing a sustainability-driven entrepreneurship curriculum as a social learning process: A case study from an international knowledge alliance project. J. Clean. Prod. 2018, 172, 4357-4366. [CrossRef]

12. Phuong, L.T.H.; Tuan, T.D.; Phuc, N.T.N. Transformative social learning for agricultural sustainability and climate change adaptation in the Vietnam Mekong Delta. Sustainability 2019, 11, 6775. [CrossRef]

13. Rogge, N.; Theesfeld, I.; Strassner, C. The potential of social learning in community gardens and the impact of community heterogeneity. Learn. Cult. Soc. Interact. 2020, 24, 100351. [CrossRef]

14. Chaves, M.; Macintyre, T.; Verschoor, G.; Wals, A.E. Towards transgressive learning through ontological politics: Answering the "call of the mountain" in a Colombian network of sustainability. Sustainability 2017, 9, 21. [CrossRef]

15. Dall'Alba, G. Learning professional ways of being: Ambiguities of becoming. Educ. Philos. Theory 2009, 41, 34-45. [CrossRef]

16. Sandberg, J.; Pinnington, A.H. Professional competence as ways of being: An existential ontological perspective. J. Manag. Stud. 2009, 46, 1138-1170. [CrossRef]

17. Sol, J.; Beers, P.J.; Wals, A.E.J. Social learning in regional innovation networks: Trust, commitment and reframing as emergent properties of interaction. J. Clean. Prod. 2013, 49, 35-43. [CrossRef]

18. Smith, T.; Holmes, G.; Paavola, J. Social underpinnings of ecological knowledge: Business perceptions of biodiversity as social learning. Organ. Environ. 2020, 33, 175-194. [CrossRef]

19. Sachs, I. Transition Strategies towards the 21st Century; Interest Publications: New-Delhi, India, 1993.

20. UN United Nations. The Sustainable Development Goals. 2015. Available online: https://www.un.org/sustainabledevelopment/ poverty/ (accessed on 14 July 2020). 
21. Broto, V.C.; Dewberry, E. Economic crisis and social learning for the provision of public services in two Spanish municipalities. J. Clean. Prod. 2016, 112, 3018-3027. [CrossRef]

22. Heidegger, M. Being and Time; Stambaug, J., Translator; Revised 1996; State University of New York Press: Albany, NY, USA, 1927.

23. Blake, J.; Sterling, S.; Goodson, I. Transformative learning for a sustainable future: An exploration of pedagogies for change at an alternative college. Sustainability 2013, 5, 5347-5372. [CrossRef]

24. Rynes, S.; Gephart, R.P., Jr. From the Editors: Qualitative Research and the Academy of Management Journal. Acad. Manag. J. 2004, 47, 454-462.

25. Geertz, C. The Interpretation of Cultures; Basic Books: New York, NY, USA, 1973.

26. Riessman, C.J. Narrative Methods for the Human Sciences; Sage Publications: Thousand Oaks, CA, USA, 2008.

27. Boje, D.M. Narrative Methods for Organizational \& Communication Research; Sage Publication: London, UK, 2010.

28. IBGE. Instituto Brasileiro de Geografia e Estatística. Censo Agropecuário 2017. Resultados Definitivos. 2017. Available online: https:/ / sidra.ibge.gov.br/pesquisa/censo-agropecuario/censo-agropecuario-2017 (accessed on 14 July 2020).

29. INCRA. Instituto Nacional de Colonização e Reforma Agrária. Painel de Assentamento. Available online: http:/ / painel.incra. gov.br/sistemas/index.php (accessed on 14 July 2020).

30. Incaper. Instituto Capixaba de Pesquisa, Assistência Técnica e Extensão Rural. Programa de Assistência Técnica e Extensão Rural Proater 2011-2013-Ecoporanga. Available online: https:/ / bibliotecaruitendinha.incaper.es.gov.br/ (accessed on 14 July 2020).

31. Cundill, G.; Lotz-sisitkab, H.; Mukuteb, M.; Belayb, M.; Shackletona, S.; Kulundub, I. A reflection on the use of case studies as a methodology for social learning research in sub Saharan Africa. NJAS Wagen. J. Life Sci. 2014, 69, 39-47. [CrossRef]

32. Jacobi, P.R.; Franco, M.I. AprendizAgem Social. SP Perspect. 2006, 20, 5-18.

33. Decree $n^{\circ} 433,24$ January 1992. Dispõe Sobre a Aquisição de Imóveis Rurais, Para Fins de Reforma Agrária, por meio de Compra e Venda. Available online: http:/ / www.planalto.gov.br/ccivil_03/decreto/D0433.htm (accessed on 14 July 2020).

34. Ríos, I.; Rivera, M.; García, C. Redefining rural prosperity through social learning in the cooperative sector: 25 years of experience from organic agriculture in Spain. Land Use Policy 2016, 54, 85-94. [CrossRef]

35. Albertus, M. Land Reform and Civil Conflict: Theory and Evidence from Peru. Am. J. Pol. Sci. 2019, 64, 256-274. [CrossRef]

36. Albertus, M.; Kaplan, O. Land Reform as a Counterinsurgency Policy. J. Conflict Resolut. 2012, 57, 198-231. [CrossRef]

37. South Africa Government. Land Reform 2021. Available online: https:/ / www.gov.za/issues/land-reform\#vision2030 (accessed on 2 June 2021).

38. Hall, R.; Kepe, T. Elite capture and state neglect: New evidence on South Africa's land reform. Rev. Afr. Polit Econ. 2017, 44, 122-130. [CrossRef] 